\title{
TINJAUAN BUKU
}

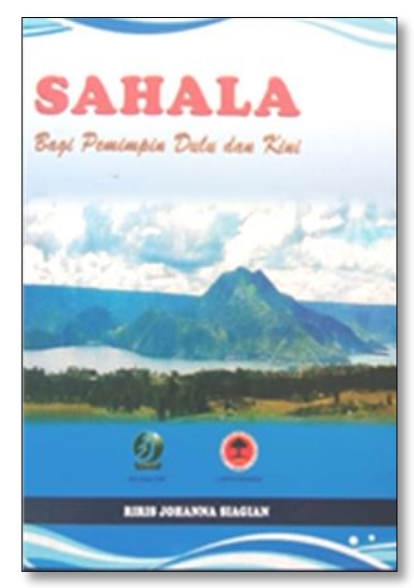

$\begin{array}{lll}\text { Judul } & : & \text { SAHALA: } \\ & \text { Bagi Pemimpin Dulu dan Kini } \\ \text { Penulis } & : & \text { Riris Johanna Siagian } \\ \text { Terbit } & : & 2019 \\ \text { Halaman } & : & 268 \\ \text { ISBN } & : & 978-602-60437-0-2 \\ \text { Penerbit } & : & \text { Lembaga Bina warga HKBP \& L- } \\ & & \text { SAPIKA Indonesia }\end{array}$

\section{Ratna Saragih}

Institut Agama Kristen Negeri Tarutung ratnasaragih12@yahoo.co.id

Bagi pembaca yang masih asing dengan istilah "sahala", jika hanya membaca judulnya saja kemungkinan akan menduga bahwa buku ini tidak berkaitan dengan teologi Kristen atau dengan gereja. Namun sebenarnya buku ini adalah sebuah buku teologi Kristen.

Kata "Sahala" didefinisikan oleh penulis sebagai energi spiritualitas unggul, kualitas unggul, dan karakter unggul di dalam diri pemimpin (h. 28). Konsep ini hidup di dalam agama Batak Toba namun sempat tenggelam akibat tekanan pengaruh Islam, misionaris Kristen, dan Pemerintah Kolonial Belanda" (h.xii, 208). Penulis menilai bahwa menurunnya anutan terhadap sahala menjadikan banyak pemimpin 
semakin egois dan tidak lagi mengutamakan kesejahteraan sesama (h.23).

Melalui buku ini, penulis berusaha merevitalisasi konsep sahala yang dianggapnya sebagai nilai-nilai luhur dalam "teologi agama Batak". Upaya ini dilakukannya terhadap mitos dan biografi para tokoh agama Batak dan agama Kristen sebagai sumber berteologi (h.205). Penulis meneliti kualitas sahala para tokoh tersebut, yakni: spiritualitas unggul, kualitas unggul, dan karakter unggul. Pada akhirnya, menurut penulis, tokoh yang memenuhi ketiga kualitas itulah yang bisa dikategorikan sebagai pemimpin ber-sahala (h.208).

Upaya merevitalisasi nilai-nilai sahala di dalam konteks agama Batak Toba Kristen, mengantar penulis melahirkan Teologi Sahala. Dengan konsep Teologi Sahala, penulis berharap dapat mentransformasikan sahala ke dalam hidup gereja dan masyarakat di masa kini untuk membentuk karakter para pemimpin yang ber-sahala atau marshala. Ini merupakan kontribusi penting bagi pelayanan gereja yang membutuhkan pemimpin berkarakter baik.

Namun demikian ada beberapa hal yang masih bisa dikritisi dari buku ini. Pertama, sahala pemimpin yang dibahas cenderung bersifat elitis, seolah-olah sahala hanya milik para elite agama Kristen dan agama Batak. Padahal penulis sendiri mengemukakan bahwa sahala itu bersifat universal. Siapa saja dapat ber-sahala. Sahala dapat diasah, dilatih atau dipraktekkan. 
Kedua, tentang kepemimpinan atau ketokohan perempuan. Dari semua tokoh yang diteliti penulis hanya satu orang perempuan, yaitu Maria Siregar (h.121-122). Apakah memang tidak ada lagi kisah tokoh perempuan yang marsahala yang juga bisa diteliti? Penulis mengatakan bahwa ketimpangan gender yang terjadi di gereja dan masyarakat penyebab utamanya bukan semata-mata soal jenis kelamin (bias gender), melainkan sejatinya adalah soal pembentukan karakter (h.xvii). Sepertinya argumentasi ini masih bisa dipertanyakan.

Ketiga, pembahasan definisi sahala yang terlalu panjang seperti tercantum pada bab II yang berjumlah 29 halaman. Untuk sebuah disertasi ulasan yang panjang mengenai definisi tersebut memang baik untuk menghindari kesalahpahaman. Namun tampaknya akan lebih mudah dipahami oleh pembaca jika diuraikan lebih padat.

Terlepas dari itu, buku Sahala: bagi Pemimpin Dulu dan Kini ini merupakan salah satu karya penting yang patut diapresiasi dan dirujuk dalam rangka studi terhadap agama suku dan kearifan lokal. Buku ini juga memperkaya studi tentang agama suku Batak. Dalam khasanah teologi kontekstual, buku ini memberi contoh bagaimana sumber-sumber tertulis (kuno) dalam bentuk narasi, bahkan oral history, dapat digunakan sebagai sumber berteologi. 